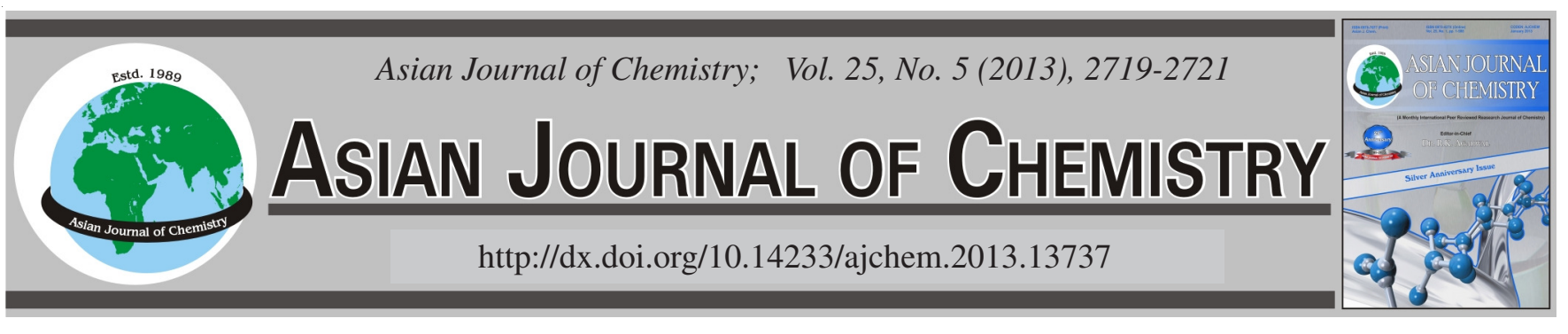

\title{
Synthesis and Antimicrobial Activity of Aluminium(III), Nickel(II) and Zinc(II) Schiff base Complexes Derived from $o$-Phenylenediamine and Salicylaldehyde
}

\author{
Mohie E.M. Zayed and Reda M. El-Shishtawy*
}

Chemistry Department, Faculty of Science, King Abdulaziz University, P.O. Box 80203, Jeddah 21589, Saudi Arabia

*Corresponding author: Fax: +966 2695 2292; Tel: +966 564666907; E-mail: elshishtawy@ hotmail.com

$\mathrm{N}_{2} \mathrm{O}_{2}$ tetradentate Schiff base ligand was synthesized from salicylaldehyde and $o$-phenylenediamine. This ligand was reacted with $\mathrm{Al}(\mathrm{III})$, $\mathrm{Ni}(\mathrm{II})$ and $\mathrm{Zn}$ (II) ions to yield the corresponding complexes. The ligand and its complexes have been characterized by IR, ${ }^{1} \mathrm{H} \mathrm{NMR}$ and elemental analysis. The spectral data of these compounds are discussed in connection with the structural changes due to complexation. The complexes prepared showed good antibacterial activities. The activity data show that the $\mathrm{Al}(\mathrm{III}), \mathrm{Ni}$ (II) and $\mathrm{Zn}$ (II) complexe are more potent antibacterial than the parent Schiff base ligand and among all $\mathrm{Al}(\mathrm{III})$ complex was the highest.

Key Words: Salicylaldehyde, Phenylenediamine, Tetradentate Schiff base, Characterization, Antimicrobial activity.

\section{INTRODUCTION}

Metals complexes using a variety of polydentate ligands are very important in several fields of science and technology ${ }^{1-4}$. They can give a wide variety of model compounds, to mimic, simulate, or modify biological and physical properties ${ }^{5,6}$. An important number of polydentate ligands that have been reported to date are Schiff bases ${ }^{7-10}$. A large number of Schiff bases and their complexes are of significant interest and attention because of their biological activity including antitumor, antibacterial, fungicidal and anti-carcinogenic properties $^{11,12}$. Tetradentate Schiff bases derived from salicylaldehyde and diamine has been the subject of many studies ${ }^{13,14}$.

We report in this paper, the synthesis and antibacterial activity of bis-hydroxybenzylidene-1,2-phenylene diamine Schiff base and its $\mathrm{Al}(\mathrm{III}), \mathrm{Ni}(\mathrm{II})$ and $\mathrm{Zn}$ (II) complexes. The prepared ligand and complexes were characterized by elemental analysis, infrared and ${ }^{1} \mathrm{H}$ NMR spectra. Also, assessment for the antimicrobial activity of these compounds against Escherichia coli, Staphylococcus aureus and Candida albicans were reported.

\section{EXPERIMENTAL}

$o$-Phenylenediamine, salicylaldehyde, aluminum chloride hexahydrate, zinc nitrate and nickel acetate tetrahydrate were of the highest purity available, purchased from Sigma-Aldrich company and used as received. Solvents were of analytical grade. ${ }^{1} \mathrm{H}$ NMR spectra were recorded in DMSO- $d_{6}$ solutions on a Bruker Avance $600 \mathrm{MHz}$ spectrometer. Infrared spectra were performed on a Perkin Elmer spectrum 100 FTIR spectrometer. Elemental microanalyses were performed at the Cairo University Microanalytical Center. Melting points were determined in open capillary tubes in a Stuart Scientific melting point apparatus $\mathrm{SMP}_{3}$ and are uncorrected.

Synthesis of $\mathrm{N}_{2} \mathrm{O}_{2}$ Schiff base $\left(\mathrm{H}_{2} \mathrm{~L}\right)$ : A mixture of $o$ phenylenediamine $(1.08 \mathrm{~g}, 10 \mathrm{mmol})$ and salicylaldehyde $(2.44,20 \mathrm{mmol})$ in absolute ethanol $(30 \mathrm{~mL})$ was refluxed for $2 \mathrm{~h}$. The orange solid Schiff base was filtered off and recrystallized from dioxane. Yield $85 \%$ (2.67 g) ; m.p. 162-164 ${ }^{\circ} \mathrm{C}$; Anal. calcd. for $\mathrm{C}_{20} \mathrm{H}_{16} \mathrm{~N}_{2} \mathrm{O}_{2}$ (316.36) C, 75.93; H, 5.10; N, 8.85. Found C, 76.56; H, 4.78; N, 8.96. IR $\left(\mathrm{cm}^{-1}\right)$ : $2710(\mathrm{OH})$, $1611(\mathrm{C}=\mathrm{N}), 1585,1561,1480(\mathrm{C}=\mathrm{C}), 1276(\mathrm{C}-\mathrm{O}) .{ }^{1} \mathrm{H}$ NMR $(\delta, \mathrm{ppm}): 12.97(\mathrm{~s}, 2 \mathrm{H},=\mathrm{Ar}-\mathrm{OH}), 8.95(\mathrm{~s}, 2 \mathrm{H}, \mathrm{CH}=\mathrm{N}), 6.96-$ 7.68 (m, 12H, Ar-H).

Synthesis of metal complexs: To a hot solution of the Schiff base $(0.22 \mathrm{~g}, 0.7 \mathrm{mmol})$ in $10 \mathrm{~mL}$ methanol/chloroform $(3: 1 \mathrm{v} / \mathrm{v})$ containing triethylamine $(0.076 \mathrm{~g}, 0.75 \mathrm{mmol})$ a hot solution of metal salt $(0.7 \mathrm{mmol})$ in $10 \mathrm{~mL}$ methanol was added. The reaction mixture was refluxed for $2 \mathrm{~h}$. The mixture was concentrated and cooled. The complex that separated out was filtered, washed twice with cold ethanol and dried.

$\operatorname{AlCl}(\mathbf{L}) \cdot 2 \mathrm{H}_{2} \mathrm{O}$ : m.p. $>340{ }^{\circ} \mathrm{C}$; Anal. calcd. for $\mathrm{C}_{20} \mathrm{H}_{18} \mathrm{~N}_{2} \mathrm{O}_{4} \mathrm{AlCl}(412.80) \mathrm{C}, 58.19 ; \mathrm{H}, 4.39 ; \mathrm{N}, 6.79$. Found C, 58.74; H, 4.16; N, 6.88. IR $\left(\mathrm{cm}^{-1}\right): 2892(\mathrm{OH}), 1617(\mathrm{C}=\mathrm{N})$, 1589, 1546, $1473(\mathrm{C}=\mathrm{C}), 1308(\mathrm{C}-\mathrm{O}) .{ }^{1} \mathrm{H}$ NMR $(\delta, \mathrm{ppm}): 9.34$ (s, 2H, CH=N), 6.85-8.16 (m,12H, Ar-H).

$\mathrm{Ni}(\mathbf{L})$ : m.p. $>340{ }^{\circ} \mathrm{C}$; anal. calcd. for $\mathrm{C}_{20} \mathrm{H}_{14} \mathrm{~N}_{2} \mathrm{O}_{2} \mathrm{Ni}$ (373.03) C 64.40, N, 7.51. Found C, 64.81; N, 7.66. IR $\left(\mathrm{cm}^{-1}\right)$ : 
$2920(\mathrm{OH}), 1602(\mathrm{C}=\mathrm{N}), 1575,1512,1438(\mathrm{C}=\mathrm{C}), 1337$ $(\mathrm{C}-\mathrm{O}) .{ }^{1} \mathrm{H}$ NMR $(\delta, \mathrm{ppm}): 8.93(\mathrm{~s}, 2 \mathrm{H}, \mathrm{CH}=\mathrm{N}), 6.68-8.18(\mathrm{~m}$, $12 \mathrm{H}, \mathrm{Ar}-\mathrm{H})$.

$\mathbf{Z n}(\mathbf{L}) \cdot \mathrm{H}_{2} \mathrm{O}$ : m.p. $>340^{\circ} \mathrm{C}$; anal. calcd. for $\mathrm{C}_{20} \mathrm{H}_{16} \mathrm{~N}_{2} \mathrm{O}_{3} \mathrm{Zn}$ (397.74) C 60.39, N, 7.04. Found C, 60.71; N, 7.20. IR $\left(\mathrm{cm}^{-1}\right)$ : $2923(\mathrm{OH}), 1614(\mathrm{C}=\mathrm{N}), 1587,1529,1459(\mathrm{C}=\mathrm{C}), 1323$ $(\mathrm{C}-\mathrm{O}) .{ }^{1} \mathrm{H}$ NMR $(\delta, \mathrm{ppm}): 9.04(\mathrm{~s}, 2 \mathrm{H}, \mathrm{CH}=\mathrm{N}), 6.52-7.93(\mathrm{~m}$, $12 \mathrm{H}, \mathrm{Ar}-\mathrm{H})$

Antimicrobial activity: The antimicrobial activities were carried out according to the conventional agar diffusion test ${ }^{15}$ using plate-technique method. The tested microorganisms were gram positive bacteria (Staphylococcus aureus NRRL B-313), NRRL B-94, gram negative bacterium (Escherichia coli NRRL B-210) and yeast (Candida albicans NRRL Y-477). The used medium was nutrient agar and the incubation period of the tested microorganisms was $24 \mathrm{~h}$.

\section{RESULTS AND DISCUSSION}

Synthesis of the $\mathrm{H}_{2} \mathrm{~L}$ ligand and its metal complexes are shown in Scheme-I. The ligand was easily obtained by condensation of 1:2 molar ratio of $o$-phenylenediamine and salicylaldehyde, respectively. This ligand is tetradentate $\mathrm{N}_{2} \mathrm{O}_{2}$ donor set and reacts by equimolar ratios with $\mathrm{Al}(\mathrm{III}), \mathrm{Ni}$ (II) and $\mathrm{Zn}(\mathrm{II})$ ions to yield stable complexes in good yield. The elemental analysis data of the $\mathrm{H}_{2} \mathrm{~L}$ and its complexes are consistent with the calculated results from the empirical formula of each compound.

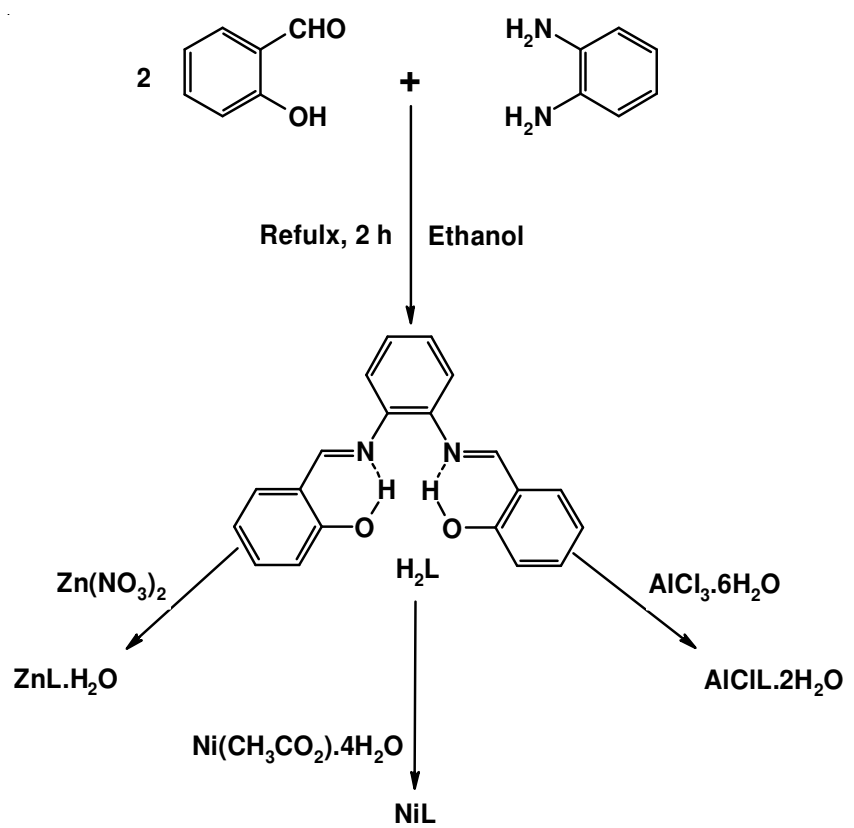

Scheme-I: Synthesis of $\mathrm{N}_{2} \mathrm{O}_{2}$ Schiff base and its metal complexes

Infrared spectra: Tracing the characteristic peaks (C-O, $\mathrm{C}=\mathrm{N}, \mathrm{OH})$ in $\mathrm{H}_{2} \mathrm{~L}$ before and after complexation would be useful to confirm the complexation. The vibrational peak of $\mathrm{C}-\mathrm{O}$ at $1276 \mathrm{~cm}^{-1}$ present in $\mathrm{H}_{2} \mathrm{~L}$ changed upon complexation to appear at 1308,1337 and $1323 \mathrm{~cm}^{-1}$ for AlClL. $2 \mathrm{H}_{2} \mathrm{O}, \mathrm{NiL}$ and $\mathrm{ZnL} . \mathrm{H}_{2} \mathrm{O}$, respectively.

Also, the vibrational peak of $\mathrm{C}=\mathrm{N}$ at $1611 \mathrm{~cm}^{-1}$ present in $\mathrm{H}_{2} \mathrm{~L}$ changed upon complexation to appear at 1617, 1602 and $1614 \mathrm{~cm}^{-1}$ for AlClL. $2 \mathrm{H}_{2} \mathrm{O}$, NiL and $\mathrm{ZnL} . \mathrm{H}_{2} \mathrm{O}$, respectively. This frequency shift indicates the coordination of the azomethine nitrogen and bonding with oxygen in all the complexes.

Furthermore, the IR spectra of the ligands also showed a broad and a weak band at $2710 \mathrm{~cm}^{-1}$, which confirms the intramolecular hydrogen bonded $\mathrm{OH}^{13,16}$. This weak peak become stronger and broader up to $3400 \mathrm{~cm}^{-1}$ upon complextion with $\mathrm{Al}(\mathrm{III})$ and $\mathrm{Zn}(\mathrm{II})$ indicating that water molecules are coordinated to the central metal ion as supported by the results of elemental analysis.

${ }^{1}$ H NMR spectra: As reported in the experimental section, the chemical shift observed for the $\mathrm{OH}$ protons in the ligand (12.97 ppm) was not observed in any of the complexes. This confirms the bonding of oxygen to the metal ions (C-O-M). The same result was confirmed by the IR spectra. Also, the variation of the chemical shift of $\mathrm{CH}=\mathrm{N}$ and aromatic protons in $\mathrm{H}_{2} \mathrm{~L}$ and its metal complexes clearly indicates that the magnetic environment has become different upon complexation and dependent on the metal type.

Antimicrobial activity: The synthesized ligand and its complexes were assessed for their antimicrobial activity. As shown in Table-1, the results revealed that complexes are more antibacterial than the ligand. On the other hand, antiyeast activity was not observed for all compounds. Al(III) and Zn(II) complexes were much more bacterial active than $\mathrm{Ni}(\mathrm{II})$ and among all $\mathrm{Al}(\mathrm{III})$ complex was the highest.

\begin{tabular}{|c|c|c|c|}
\hline \multicolumn{4}{|c|}{$\begin{array}{c}\text { TABLE-1 } \\
\text { ANTIMICROBIAL ACTIVITY DATA FOR THE } \\
\text { LIGAND AND ITS COMPLEXES }\end{array}$} \\
\hline \multirow{2}{*}{$\begin{array}{l}\text { Ligand/ } \\
\text { complex }\end{array}$} & \multicolumn{3}{|c|}{ Inhibition zone $\mathrm{e}^{\mathrm{a}}$} \\
\hline & $\begin{array}{c}\text { Escherichia } \\
\text { coli }\end{array}$ & $\begin{array}{c}\text { Staphylococcus } \\
\text { aureus }\end{array}$ & $\begin{array}{l}\text { Candida } \\
\text { albicans }\end{array}$ \\
\hline $\mathrm{H}_{2} \mathrm{~L}$ & ++ & - & - \\
\hline AlClL. $2 \mathrm{H}_{2} \mathrm{O}$ & +++ & ++ & - \\
\hline $\mathrm{NiL}$ & +++ & - & - \\
\hline $\mathrm{ZnL} . \mathrm{H}_{2} \mathrm{O}$ & ++ & ++ & - \\
\hline
\end{tabular}

The activities of these complexes may be explained on the basis of chelation theory; chelation reduces the polarity of the metal atom mainly because of partial sharing of its positive charge with the donor groups and possible $\pi$-electron delocalization within the whole chalete ring. Also, chelation increases the lipophelic nature of the central atom which subsequently favours its permeation through the lipid layer of the cell membrane ${ }^{17}$.

\section{REFERENCES}

1. X.-G. Zhou, J.-S. Huang, Z.-Y. Zhou, K.-K. Cheung and Ch-.M. Che, Inorg. Chim. Acta, 331, 194 (2002).

2. D.M. Boghael and S. Mohebi, J. Mol. Catal. A, 179, 41 (2002).

3. A. Pui, I. Berdan, I. Morgenstern-Badarau, A. Gref and M. Peree-Fauvet, Inorg. Chim. Acta, 320, 167 (2001).

4. L.A. Kovbasyuk, I.O. Fritzky, V.N. Kokozay and T.S. Iskenderov, Polyhedron, 16, 1723 (1997).

5. M.R. Bermejo, A. Sousa, A. García-Deibe, M. Maneiro, J. Sanmartín and M. Fondo, Polyhedron, 18, 511 (1999).

6. F. Tuna, L. Patron and M. Andruh, Inorg. Chem. Commun., 6, 30 (2003).

7. G.B. Gill, G. Pattenden and S.J. Reynolds, J. Chem. Soc., Perkin Trans. I, 369 (1994); D.J. Coveney, V.F. Patel, G. Pattenden and D.M. Thompson, J. Chem. Soc., Perkin Trans. I, 2721 (1990). 
8. R. Irie, K. Noda, Y. Ito, N. Matsumoto and T. Katsuki, Tetrahedron: Asymm., 2, 481 (1991).

9. L. Deng and E.N. Jacobsen, J. Org. Chem., 57, 4320 (1992); E.N. Jacobsen, L. Deng, Y. Furukawa and L.E. Martinez, Tetrahedron, 50, 4323 (1994).

10. K. Imagawa, T. Negata, T. Yamada and T. Mukaiyama, Chem. Lett., 527, (1994); C. Bolm, Angew. Chem., 103, 414 (1991); Angew. Chem. Ed. Engl., 30, 403 (1991).

11. S. Ren, R. Wang, K. Komatsu, P. Bonaz-Krause, Y. Zyrianov, C.F. Mckenna, C. Csipke, Z.A. Tokes and E.J. Lien, J. Med. Chem., 45, 410 (2002).

12. N. Raman, A. Thangaraja and C. Kulandaisamy, Transition Met. Chem., 28, 29 (2003).
13. J.-N. Liu, B.-W. Wu, B. Zhang and Y.C. Liu, Turk. J. Chem., 30, 41 (2006).

14. A.A.A. Aziz, J. Mol. Struct., 979, 77 (2010) and references cited therein.

15. D. Greenwood, Antimicrobial Chemotherapy, Part II. Laboratory Aspects of Antimicrobial Therapy, Bailliere, Tindall, London, p. 71 (1983).

16. M.R. Mahmoud, S.A. Ibrahim and N.M. Ismail, Monatsh. Chem., 116, 167 (1985).

17. M.M. Abd-Elzaher, Appl. Organometal. Chem., 18, 149 (2004) and references cited therein. 